\title{
Changing Places: Where Will We Be with Our Patients? A Perspective from the Keystone IV Conference
}

Kim Strong Griswold, $M D, M P H$

Dr. Stephens knew a lot about place - his place within family medicine and the place of family medicine as a catalyst for change in our communities. In "G. Gayle Stephen's Festschrift," the evolution of our profession is mirrored by Dr. Stephen's seminal contributions to practice and service to his discipline. He describes our place as healers, teachers, scholars, builders, moral agents, professionals, and reformers. Stephen's place-changing career and ethos pave the way for our place as advocates for our patients and change agents for family medicine in this newest millennium. ( $\mathrm{J}$ Am Board Fam Med 2016; 29:S24-S27.)

Guest editors' note: This article was commissioned to help prepare attendees for participation in the G. Gayle Stephens Keystone IV Conference. It exposes the complexity of "place" in primary care, revealing the importance of meeting patients where they are and how community becomes the place where the promises of personal physicians must be kept.

Keywords: Doctoring, Family Medicine, Family Physician, Health Care Delivery, Personal Physician, Population Health, Primary care, Professionalism, Social Justice

Dr. Stephens knew a lot about place-his place within family medicine and the place of family medicine as a catalyst for change in our communities. In "G. Gayle Stephens's Festschrift," the evolution of our profession is mirrored by Dr. Stephens's seminal contributions to practice and service to his discipline. He describes our place as healers, teachers, scholars, builders, moral agents, professionals, and reformers. Stephens's place-changing career and ethos pave the way for our place as advocates for our patients and as change agents for family medicine in this newest millennium.

This article was externally peer reviewed.

Submitted 4 January 2016; revised 26 March 2016; accepted 1 April 2016.

From the Department of Family Medicine, State University of New York at Buffalo.

Funding: none.

Conflict of interest: none declared.

Corresponding author: Kim Strong Griswold, MD, MPH, Department of Family Medicine, State University of New York at Buffalo, 77 Goodell Street, Buffalo, NY 14203 (E-mail: griswol@buffalo.edu).
Place is from Middle English, meaning "open space," and is a synonym of "where." When I think about place in the context of family medicine, I consider the sense of place for patients, places we practice, how place intersects with time, with relationships, with specific geography. In her essay "People Are Primary," Etz asks what promises we can make "about when and where (we) will 'be there' for others." 2 Being there must harness not only a Google map of current location but also a physical presence that can allow a synergy of compassion communicated between 2 or more people.

In the 21 st century, places to deliver and receive care may differ. Place may have a lot to do with comfort and where doctors and patients feel comfortable. The places where physicians and patients can best listen to one another seem to be those places/spaces where the acts of healing, advocacy, and teaching can work to best advantage.

I think we have an evolving sense of place for primary care-informed by history, infused by technology, and insisted on by patients. One of the 
most important promises we make as primary care physicians is to meet our patients where they are, emotionally and geographically. In his 1979 essay "Family Medicine as Counterculture," Dr. Stephens describes how family physicians embrace those places not always considered mainstream: rural medicine, care of the vulnerable and underserved, investment in personal medicine, patient education, and advocacy. ${ }^{3}$ He was influenced not only by his own experience but by the important reports that laid the foundation for our specialty. $\mathrm{He}$ and we embrace those places where need is greatest-and serve in places hard to get to.

Our care of vulnerable populations illustrates how vital it is to understand and learn about the cultural context and place of the patient and how we can create an inviting space as physicians and teams. Whole-person care for individuals with serious mental health concerns, or who are homeless, often calls for an extension of care out from the medical home to the neighborhood. It might be thought of as "place-shifting" so that there is a potential bidirectional movement between "homes"- those of patients and those of our community health services.

As Keystone put into sharp focus, the stories we and our patients live, the stories we tell, and the stories yet to be written describe and signify that family medicine, more than any other specialty, creates a place for all patients.

In the Folsom Report, the community becomes the place of action: "Success . . . will require removal of racial, economic, organizational, residence, and geographic barriers to the use of health services." The Folsom promise emphasized eliminating the boundaries that fracture places of care. ${ }^{4}$

A community of solution is a "place" where the alchemy between a community, public health, and primary care culminates in optimal patient-centered service. ${ }^{5}$ From the inception of our specialty, the community has been our power base, natural environment, and foundation for growth. Stange et $\mathrm{al}^{6}$ emphasize that "since a fundamental benefit of primary care is its adaptability to diverse people, populations and systems, functional patient-centered medical homes (PCMHs) will look different in different settings."

So the PCMH may reflect community, but does the transformative power of the PCMH provide the answer to all in a community seeking a place of care? Where do we meet the people who do not seek care? Or meet those who find it difficult to make connections? Dr. Bliss ${ }^{7}$ argues that one of our fundamental problems is that "the patient is still mainly an afterthought, an object of the system rather than an active participant, generator of ideas, or source of pressure for change . . patients have no power within the system." She suggests that in a truly responsive and creative system of primary care, patients and medical homes would have options in terms of payment and in terms of place (for example, home-based care and telemedicine).

\section{The Patient Will See You Now (the Doctor's Office May Be Anywhere)}

Traditionally, in the days of Marcus Welby, patients saw the doctor in the doctor's own home, but just as likely the doctor made house calls. Over the past half century, care swung mostly into officebased practice. Doctors had less time and garnered less reimbursement from stepping out of the office and into the intimacy of patients' lives.

Today, we're looking at a sea change in our primary care system-that idiom from Shakespeare's The Tempest signifying transformation. The sense of urgency felt for immediate response (from texting, iMmessage, Reddit, Instagram, etc.), the importance of convenience, are creating new paradigms of how and where doctors and patients meet. Patients from their own home can "video chat" with a doctor, ${ }^{8}$ can wear diagnostic "implantables," or use the patient portal of the electronic medical record. Telemedicine in rural areas, or overseas, provides remote health care and a continuity of connection through highspeed fiberoptic cables.

Given the miraculous complexity of technology and artificial intelligence, where do patients want medical providers? Will virtual care do? Convenience is promoted when "Duane Reade Launches DR Walk-in Medical Care," or "In Rural Virginia, Truckers Can Stop for Coffee and a Physical." 10 And when you as the patient are sick-even very sick-would not you rather be home? "Admitted to Your Bedroom," "some medical centers . . . hospitalize patients in their home."11

\section{Where Are the Patients?}

Forty years after the Folsom Report, still focusing on where we need to be, the precepts of public health and the meaningful use of data find the patients who need us most in primary care, who are 
"super utilizers," whose place is often the hospital, or who have no place. ${ }^{12} \mathrm{We}$ are finding and mapping places that contribute to disparity or help to make our neighborhoods whole. ${ }^{13}$ Health-focused communities of solution identify "cold-spots" of dis-integrated care and find the assets within that area to provide a local solution. ${ }^{14}$

The PCMH has driven the development and illuminated the importance of team-based care. The team calls for many different professionals, versed in the determinants of health and with a broader array of skills than those of a single physician. Far from "squeezing out the doctor," ${ }^{15}$ I think that team caring allows the physician to do what he or she does best: the art of paying exquisite attention to patients. In the setting of interprofessional support, does continuity of place matter as much as continuity of care? And might not the place of the patient-in his or her home, at a medical home, in a community setting - provide the milieu that allows us to understand better the important interplay of health, illness, and dis-ease.

\section{Our Sense of Place; Promises}

Dr. Stephens said in his "counterculture" essay: "We are benevolent, well-intentioned, humble country doctors who only want to restore some balance to medicine. We do not want to destroy anything, or take anything away from anybody; we just want a place in the sun for ourselves and our residents and students."

In June 2015 the Commonwealth Fund published new rules for health care redesign, emphasizing the movement of knowledge; 5 of the rules can inform our sense of place going forward: change the balance of power, customize to individuals, collaborate, eliminate walls, and create joy in work. ${ }^{16}$ Wherever care is delivered, we can promise to:

- Meet and delight in patients where they are

- Continue to cultivate communities of solution

- Remember the place of touch in healing

Ultimately, I believe our place is the primary care partnership we have with our patients. This is reflected by our commitment to caring for and with people from birth through the end of life. We have strong places for leadership in health care, and for research and scholarship that will continue the sea change of our specialty and ensure its resilience. Finally, we have a mission for teaching and mentoring those who will take our-place.

\section{References}

1. Geyman JP. G. Gayle Stephens Festschrift. Fam Med 2011;43:7-12.

2. Etz RS. People are primary. Keystone IV Supplement. J Am Board Fam Med 2016;29(Suppl1):S40-S44.

3. Stephens GG. Family medicine as counterculture. Fam Med 1989;21:103-9.

4. National Commission on Community Health Services. Health is a community affair. Cambridge, MA: Harvard University Press; 1966.

5. Folsom Group. Communities of solution: the Folsom Report revisited. Ann Fam Med 2012:10:250-60.

6. Stange KC, Nutting PA, Miller WL, et al. Defining and measuring the patient-centered medical home. J Gen Intern Med 2010;25:601-12.

7. Bliss E. The primary care medical home: whose home is it? Reaction to the paper by Karen Davis, PhD, and Kristof Stremikis, MPP. J Am Board Fam Med 2010;23(Suppl 1):S21-2.

8. Shahani A. The doctor will video chat with you now: insurer covers virtual visits. NPR All Tech Considered, April 30, 2015. Available from: http:// www.npr.org/sections/alltechconsidered/2015/04/ 30/403346731/the-doctor-will-video-chat-withyou-now-insurer-covers-virtual-visits. Accessed May 28, 2016.

9. Duane Reade Holdings, Inc. Duane Reade launches DR walk-in medical care, the first in New York, physician present retail walk-in service. PR Newswire, May 23, 2007. Available from: http://www.prnewswire.com/ news-releases/duane-reade-launches-dr-walk-in-medical-care-the-first-in-new-york-physician-presentretail-walk-in-service-58527412.html. Accessed May 28, 2016.

10. Hausman S. In rural Virginia, truckers can stop for coffee and a physical. NPR Weekend Edition Sunday, April 5, 2015. Available from: http://www.npr. org/sections/health-shots/2015/04/05/397363105/ in-rural-virginia-truckers-can-stop-for-coffee-and-aphysical. Accessed May 28, 2016.

11. Lamas DJ. Admitted to your bedroom. New York Times, Science Times, April 28, 2015. http:// www.timeslive.co.za/sundaytimes/stnews/international/2015/05/03/admitted-to-your-bedroomsome-hospitals-try-treating-patients-at-home.

12. Gawande A. The hot spotters. New Yorker, January 24, 2011. http://www.newyorker.com/magazine/ 2011/01/24/the-hot-spotters.

13. HealthLandscape. Community HealthView. Available from: http://www.healthlandscape.org/ index.cfm? focus $=$ CommunityHealthData. Accessed May 28, 2016. 
14. Westfall JM. Cold-spotting: linking primary care and public health to create communities of solution. J Am Board Fam Med 2013;26:239-40.

15. Bangalore and Framingham. Squeezing out the doctor: the role of physicians at the centre of health care is under pressure. Economist, June 2, 2012. http://www.economist.com/node/21556227.
16. McCarthy D, Hostetter M, Klein S. "New rules" to guide health care redesign. To the Point, June 3, 2015. New York: The Commonwealth Fund. Available from: http://www.commonwealthfund.org/publications/blog/ 2015/jun/new-rules-guide-health-care-redesign? omnicid=EALERT801129\& mid=griswol@buffalo. edu. Accessed May 28, 2016. 